\title{
O ARCHIWACH SPOŁECZNYCH I ICH ZNACZENIU DLA POLSKIEGO DZIEDZICTWA NARODOWEGO ORAZ TOŻSAMOŚCI LOKALNEJ ${ }^{*}$
}

http://dx.doi.org/10.12775/AKZ.2014.005

Słowa kluczowe: archiwa społeczne; archiwa państwowe; archiwa prywatne; polskie dziedzictwo narodowe; tożsamość lokalna; współpraca międzyarchiwalna

Ke y w o r d s: community archives; state archives; private archives; Polish national heritage; local identity; inter-archival cooperation

\section{Streszczenie}

Archiwa społeczne przejawiają zwłaszcza w ostatnich kilku latach znaczną aktywność. Dzięki temu zdołały wyraźnie wpisać się jako element systemu archiwów w Polsce. Jednak szereg podstawowych problemów, bynajmniej nie tylko teoretycznych, związanych z ich działalnością, tj. ich formalny status (w tym takiż status ich zbiorów) i miejsce przypadające im w szerzej rozumianej sieci archiwów polskich oraz kształt relacji z innymi archiwami (zwłaszcza państwowymi) wymaga jeszcze sprecyzowania. Obok tego - co zresztą wiąże się z niejedną z ujętych materii - rozpatrzenia wymaga także kwe-

Artykuł stanowi rozbudowaną wersję referatu wygłoszonego 9 VI 2014 r. na Konferencji Metodycznej „Archiwa - Tożsamość - Przyszłość” w Radzyniu Podlaskim zorganizowanej przez tamtejszy oddział Archiwum Państwowego w Lublinie. 


\section{Tomasz Czarnota}

stia ich zasadniczego znaczenia z punktu widzenia dziedzictwa narodowego i tożsamości lokalnej. Przyjmując tezę Jerzego Skowronka, że archiwalne dziedzictwo narodowe odpowiada wszelkim archiwaliom wytwarzanym przez dany naród i państwo niezależnie od miejsca ich przechowywania, zasób archiwów społecznych należy za takowe uznać. Nie zawsze jednak jest on w oczywisty i wyraźny sposób kojarzony z kluczowymi z punktu widzenia narodu jako całości zjawiskami, procesami bądź wydarzeniami. Natomiast zasób ów, ze względu na zakres gromadzonych zbiorów, jest bezpośrednim, a zarazem bardzo wiernym odzwierciedleniem dziejów lokalnych. To wraz z powszechną u archiwów społecznych praktyką wciągania miejscowych społeczności do współtworzenia tych dziejów i ogólnie do współdziałania z nimi w sposób niekwestionowany ustawia je w roli czołowych kreatorów i opiekunów lokalnej tożsamości. Realizacja ich misji, widocznej w obu tamtych sferach, przebiega w warunkach swoistej dychotomii. Z jednej strony widoczne jest świadome wykorzystywanie posiadanych atutów, tj. kreatywność, zapał i szczególną umiejętność docierania do niedostępnych innym ewentualnym konkurentom źródeł. $\mathrm{Z}$ drugiej osiągnięcie pełnego powodzenia utrudniają im różne ograniczenia, zwłaszcza zauważalna często finansowa chwiejność i brak pewności trwania w dłuższej perspektywie czasowej. Z kolei archiwa państwowe, których egzystencja pod tym względem nie jest problematyczna, z przyczyn formalno-organizacyjnych nie mogą w pełni efektywnie oddziaływać na niepaństwową „odnogę" narodowego zasobu archiwalnego. To wraz z szeregiem innych przesłanek powinno skłaniać oba typy archiwów do zagęszczenia kontaktów i podejmowania lub intensyfikacji współpracy co najmniej na kilku polach. Jej rezultatem będzie zwielokrotnienie skuteczności prowadzonej przez nie z osobna działalności archiwalnej.

Archiwa społeczne głównie dzięki własnej aktywności i osiągnięciom, zwłaszcza w ostatnich kilku latach, stały się dosyć powszechnie znanym zjawiskiem widocznym na archiwalnym firmamencie. To, a także szereg publikacji na ten temat, sprawia, że kolejnych poświęconych im rozważań nie trzeba zaczynać się od przysłowiowego „Adama i Ewy”. Jest godne podkreślenia, że ich pojawienie się generalnie zbiega się z odzyskaniem przez Polskę suwerenności na przełomie dziewiątej i dziesiątej dekady ubiegłego stulecia, zaś ich dalszy rozwój odbywa się nie bez powiązań z umacnianiem się jej demokratycznego, opartego na pluralizmie ustroju. Pluralizmu, którego wyrazem, jak twierdzą niektórzy, jest m.in. różnorodność działających w danym kraju archiwów ${ }^{1}$. Przynajmniej kilka spośród dziś istniejących archiwów społecznych, takich jak warszawska Fundacja Ośrodka Karta oraz toruńska

1 T. Grygier, Zagadnienia podziatu wewnętrznego archiwistyki, „Archeion” 1979, t. 68 , s. 160 , przypis 37 . 
Fundacja Generał Elżbiety Zawackiej, sięga genezą czasów PRL. Ale wówczas przynajmniej niektórych rezultatów ich działalności starano się nie eksponować, by nie wzbudzać podejrzliwości ówczesnych władz. A ta byłaby „uzasadniona” o tyle, że - i to stanowi istotę owych ośrodków - archiwa społeczne mają to do siebie, iż powstają w efekcie celowej (dodam też, że spontanicznej i nienadzorowanej przez organy władzy publicznej) aktywności obywatelskiej². Ta ma często charakter nieformalny, choć wśród tych ostatnich są stowarzyszenia i fundacje, a niektóre działają przy różnych instytucjach, tj. biblioteki i domy kultury, a nawet przy urzędach ${ }^{3}$. Spośród nich liczebnie przeważają archiwa cyfrowe ${ }^{4}$, stanowiące najbardziej egalitarny typ archiwum $^{5}$. Zapisy ustawy archiwalnej z 14 lipca 1983 r. nakazują upatrywać w nich składowe niepaństwowego zasobu archiwalnego: ewidencjonowanego, tworzonego m.in. przez akta organizacji pozarządowych, związków zawodowych i wyznaniowych i partii politycznych, oraz nieewidencjonowanego, któremu odpowiadają archiwalia wytworzone i zebrane przez osoby fizyczne. Prawo archiwalne w obecnym kształcie nie jest jednak optymalnym regulatorem tej sfery działalności archiwalnej, której specyfika w dużej mierze wymyka się jego słabo przystającym do niej sformułowaniom. Ale także teoria i terminologia archiwalna nie nadążają za jej rozwojem. Oto przykład. Archiwa społeczne mogą prowadzić także podmioty gospodarcze ${ }^{6}$, zainteresowane nie tylko dokumentowaniem własnej działalności, lecz również historią i tradycją otoczenia, w którym funkcjonują. Celem tego może być m.in. ukazanie owemu otoczeniu ich społecznie wrażliwego oblicza oraz demonstrowanie ich długotrwałych związków z określonym terenem i jego mieszkańcami. Postawmy pytanie: czy są to archiwa „społeczne” czy raczej „prywatne”, które mają zresztą ustaloną konotację w archiwalnej terminologii? ${ }^{7}$ Chcąc na nie

2 K. Ziętal, Wstęp, [w:] Archiwistyka spoteczna, Warszawa 2012, s. 9.

3 Taż, Ustanowienie AS-ów, „Karta” 2013, nr 75, s. 138.

4 Tamże, s. 139.

5 Por. D. Magier, Archiwistyka wobec wyzwań świata cyfrowego, „Archiwista Polski” 2010, nr 4, s. 21.

${ }^{6}$ K. Ziętal, Ustanowienie AS-ów, s. 139.

7 W świetle hasła Polskiego stownika archiwalnego archiwum prywatne to zespół archiwalny (sic!) - a więc dokumentacja o jednorodnym pochodzeniu - powstały wskutek działalności instytucji prywatnej lub osoby fizycznej albo rodziny (rodu), zachowujący ten status niezależnie od miejsca jego aktualnego przechowywania (zob. Polski stownik archiwalny, red. W. Maciejewska. Warszawa 1974, s. 20). Z kolei w ujęciu proponowanym przez ekspertów UE za archiwa prywatne należy uważać ogół archiwów nie 
odpowiedzieć, trzeba zasygnalizować przynajmniej dwa kryteria pozwalające owe archiwa umiejscowić w jednej bądź w drugiej grupie. Istotą pierwszego z nich jest określenie, komu owo archiwum służy przede wszystkim. Drugie natomiast wiąże się z występowaniem - lub brakiem - ścisłego związku funkcjonalno-treściowego gromadzonej dokumentacji z podstawową działalnością danego podmiotu. Te archiwa, które udostępniając dokumentację wyłącznie lub w decydującej mierze, zaspokajają informacyjne potrzeby swych właścicieli niebędących prawnymi osobami publicznymi, jeśli jednocześnie odpowiadają kryterium funkcjonalno-treściowemu ${ }^{8}$, należy uznać za prywatne. $\mathrm{Z}$ jednym zastrzeżeniem - mianowicie, gdy ową podstawową działalnością jest ni mniej, ni więcej niedochodowa działalność archiwalna. W określeniu „archiwa społeczne” ten ostatni przymiotnik, choć bodaj nigdy nie pojawia się w ich nazwach własnych ${ }^{9}$, jest, jak przypuszczam, potrzebny do wyeksponowania ich wyraźnej odmienności zarówno od archiwów publicznych, jak i prywatnych. Istotę tych pierwszych ująłbym następująco: archiwa społeczne powstają bezpośrednio dzięki społeczeństwu, ich zasób traktuje głównie o społeczeństwie (a nie o władzy) i temuż społeczeństwu służy on przede wszystkim. W podobnym tonie wypowiadają się ich przedstawiciele ${ }^{10}$. Kwestii własności zbiorów, która może być tylko albo publiczna, albo prywatna, nie należy w tym kontekście majoryzować. Jeżeli dane archiwum stanowiące własność prywatną spełnia zawarte w owym haśle warunki, jest zarazem prywatne i społeczne. Pewne jest, że warunków tych (w zupełności) nigdy nie spełni żadne archiwum państwowe. Oczywiście, skomplikowana rzeczywistość najpewniej nie omieszka podsunąć dowodów nieistnienia „idealno-typowych” archiwów społecznych. Jednak zawsze warto podejmować próby uściślania aparatu pojęciowego archiwistyki. Lecz nie w terminologicznych zawiłościach ani w formalno-rodzajowej klasyfikacji tkwi sens podnoszenia

zdefiniowanych jako publiczne, przeważnie akt organizacji, agencji i instytucji pozarządowych, akta organizacji całkowicie niezwiązanych z rządem oraz większość archiwów rodzinnych i osobistych. Ponadto termin ten pojawia się też w znaczeniu prywatnej instytucji archiwalnej (zob. Raport o archiwach $w$ Unii Europejskiej po rozszerzeniu. Pogtebiona wspótpraca archiwalna w Europie. Plan dziatania, Warszawa 2012, s. 76, 78).

${ }^{8}$ Kryteria te powinny być spełnione kumulatywnie.

9 Dodam, że także słowo „archiwum” bardzo rzadko jest w nich obecne.

${ }^{10} \mathrm{Na}$ Międzynarodowej Konferencji Archiwa Społeczne. Modele Współpracy z Państwem (Warszawa, 6 X 2014 r.) Prezes Fundacji Ośrodka Karta Zbigniew Gluza w słowie na jej otwarcie podkreślił, że mimo skojarzeń z prywatnymi archiwami „sens” tych archiwów jest społeczny i znajdują się one w społecznych rękach. 
kwestii archiwów społecznych. Dlatego na tym kończę tę dygresję, przechodząc do problematyki ich znaczenia.

Jak podaje Stownik języka polskiego - „znaczyć” to inaczej stanowić znak (ślad) czegoś, znakować coś, być określonej treści (zawierać pewną treść), a także odgrywać ważną rolę. Z kolei „znaczenie” to albo treść wypowiedzi albo wartość czegoś ${ }^{11}$. Koncepcja tego artykułu implikuje konieczność postawienia pytania o znaczenie archiwów społecznych, tzn. podjęcia próby przypisania im określonej roli i docieczenia ich (niematerialnej) wartości. Zasadniczy punkt odniesienia stanowią dwie, skądinąd powiązane z sobą sfery, mianowicie polskie dziedzictwo narodowe i tożsamość lokalna.

Treść pojęcia dziedzictwo narodowe, choć jest ono nierzadko używane, z powodu braku ujęć definicyjnych ${ }^{12}$ trzeba samemu rekonstruować, sięgając do różnych źródeł. Stownik języka polskiego dziedzictwo objaśnia jako spadek oraz pozostawione następnym pokoleniom dobra kulturalne, duchowe etc. ${ }^{13}$ Wedle dokumentów UNESCO jest to podlegająca przekazaniu potomnym nasza historyczna spuścizna, wytwory współczesnej cywilizacji i dorobek wartościowe wytwory myśli ludzkiej ${ }^{14}$. Przymiotnik „narodowe” oznacza jego przynależność do danego narodu. Sukcesją narodu polskiego (czyli polskim dziedzictwem narodowym) jest to, czego w wielu dziedzinach, tj. kulturze, sztuce, nauce, gospodarce, stosunkach społecznych i politycznych, zdołał on w przeszłości dokonać i co jego kolejne generacje otrzymają po poprzednikach w spadku. Zaznaczam, że skupiając się na części dziedzictwa narodowego Polaków wiążącej się z materiałami archiwalnymi, abstrahuję tu od tego, co stanowi ich duchową, niepowiązaną z materialnym podłożem spuściznę. $\mathrm{Na}$ potrzeby tego dyskursu będę $\mathrm{w}$ tym znaczeniu posługiwał się terminem „narodowe dziedzictwo archiwalne” ${ }^{15}$. W połowie lat 90. XX w. ówczesny

${ }^{11}$ Hasła: „znaczenie” i „znaczyć”, zob. Stownik jezzyka polskiego, http://sjp.pl/znaczenie [dostęp: 26 V 2014 r.].

${ }_{12}$ Zob. A. Laszuk, Archiwa częścia dziedzictwa narodowego - standardy podstawa wspótpracy, [w:] Toruńskie konfrontacje archiwalne, red. W. Chorążyczewski, A. Rosa, t. 3: Archiwistyka między różnorodnością a standaryzacją, Toruń 2013, s. 175.

${ }^{13}$ Hasło „dziedzictwo”, Stownik jezyka polskiego.

${ }_{14}$ Ochrona dziedzictwa cyfrowego. Zalecenia, Warszawa 2003, s. 37.

${ }^{15} \mathrm{Na}$ temat dziedzictwa narodowego zob.: A. Laszuk, dz. cyt., s. 175-177; R. Borychowski, Archiwalne dziedzictwo narodowe a narodowy zasób archiwalny, [w:] Zatrzymać przesztość, dogonić przysztość. Pamiętnik VI Powszechnego Zjazdu Archiwistów Polskich, Wroctaw 5-7 września 2012 r., red. W. Chorążyczewski i K. Stryjkowskie, Warszawa 2013, s. 277-286. 
Naczelny Dyrektor Archiwów Państwowych prof. Jerzy Skowronek przedstawił minimalistyczny i maksymalistyczny sposób rozumienia tego pojęcia. Skłaniam się ku opowiedzeniu się za tym ostatnim, któremu odpowiada wszelka dokumentacja archiwalna wytwarzana przez dane państwo i naród, niezależnie od miejsca jej przechowywania ${ }^{16}$. Konieczne jest podkreślanie szerokiego rozumienia archiwalnego dziedzictwa, albowiem sploty wydarzeń dziejowych sprawiły, że bezspornie polskie archiwalia znajdują się obecnie w wielu archiwach poza obecnymi granicami Polski ${ }^{17}$. Szeroki sposób jego pojmowania nie stoi w sprzeczności z dostrzeganiem w nim dokumentów mających szczególne znaczenie z punktu widzenia narodu. Każdy naród i każde państwo w swym dziedzictwie archiwalnym dostrzega takie, które w większym niż inne stopniu wiążą się z jego podstawowymi prawami i tożsamością ${ }^{18}$. Tym samym przypisuje im się większą wartość. Dociekanie tego, o które obiekty chodzi, zasługuje na osobny artykuł. Nadmienię tylko, że jednym z kryteriów pozwalających je uchwycić jest zainteresowanie narodowe (objawiane przez przedstawicieli danego narodu $)^{19}$.

Dla jasności dalszego wywodu krótko odniosę się do treści pojęć, tj. dóbr kultury, dziedzictwa kulturowego i dziedzictwa kulturalnego. Dokumen-

16 Minimalistyczne rozumienie nawiązuje do dokumentów i materiałów wytworzonych przez administrację państwową i inne instytucje życia publicznego przechowywanych w archiwach państwowych i innych publicznych (zob. J. Skowronek, Misja archiwisty i problemy rewindykacji archiwów - specyfika Europy Środkowo-Wschodniej XIX i XX w., „Archeion” 1995, t. 94, s. 15). Można do tego dodać, że do tak pojmowanego dziedzictwa archiwalnego w szczególności wchodzą archiwalia przechowywane (lub do tego się kwalifikujące) w archiwach stanowiących własność państwa, w którym jak ma to miejsce w Rzeczypospolitej Polskiej, zwierzchnia władza formalnie należy do danego narodu (zob. art. 4 pkt. 1 Konstytucji Rzeczypospolitej Polskiej z 2 IV 1997 (Dz.U. $1997 \mathrm{nr} 78$, poz. 483).

17 Pisząc „polskich”, nie mam na myśli wyłącznie archiwów znajdujących się we współczesnych granicach państwa polskiego. Pojęcie to należałoby na pewno rozszerzyć na archiwa emigracji polskiej, a także Polonii. Osobnym problemem jest przechowywanie bezspornie polskiego dziedzictwa archiwalnego w archiwach obcych, zarówno należących do krajów, które toczyły kiedyś z Polską wojny i/lub dokonywały rozbiorów jej ziem, jak i usytuowanych w innych państwach. Te ostatnio weszły w ich posiadanie w okolicznościach pokojowych, zazwyczaj z woli dysponentów archiwaliów.

18 Por. W. Stępniak, Program UNESCO Memory of the World, „Archeion” 1994, t. 93, s. 131 .

19 To jedno z kryteriów, które, obok kilku innych, proponowano w 1993 r. zastosować przy typowaniu krajowych zespołów i zbiorów do programu Pamięć świata. Por. W. Stępniak, dz. cyt., s. 134. 
ty przechowywane $\mathrm{w}$ archiwach niewątpliwie mieszczą się $\mathrm{w}$ definicji tych pierwszych $^{20}$. Dziedzictwo kulturowe, czyli dobra kultury, nauki, sztuki itp. pozostawione przez poprzednie pokolenia, wedle niektórych odpowiadają dokumentacji w szerokim znaczeniu ${ }^{21}$. Natomiast archiwalnego dziedzictwa narodowego nie należy utożsamiać z dziedzictwem kulturalnym. To, wedle akceptowanej na gruncie międzynarodowym definicji, odnosi się do zabytków (dzieł architektury i sztuki monumentalnej, ale także do grot z malowidłami), zespołów budowli o podobnym znaczeniu i miejsc zabytkowych - dzieł człowieka bądź wspólnych dzieł jego i przyrody ${ }^{22}$. Przeciw włączaniu do dziedzictwa kulturalnego w brzmieniu określonym przez UNESCO dokumentacji będącej wytworem instytucji publicznych wypowiadał się Jerzy Skowronek ${ }^{23}$. Per analogiam nie powinno się włączać do niego zasobów społecznych ośrodków dokumentacyjnych.

Przyjrzyjmy się teraz kolejnemu terminowi, czyli tożsamości lokalnej. Tożsamość w najprostszym ujęciu zestawia się identycznością, a także ciągłością ${ }^{24}$. Z kolei określenie „lokalna” wiąże się z tym, a także innymi zjawiskami zachodzącymi generalnie na poziomie poniżej szczebla wojewódzkiego, kojarzonego z pojęciem regionu (administracyjnego). W odniesieniu zarówno do tożsamości lokalnej, jak i regionalnej przyjmuje się możliwość opisania tego zjawiska wielowymiarowo, za pomocą ośmiu perspektyw ${ }^{25}$ :

- psychologicznej, której kluczowym elementem jest stopień identyfikacji danej osoby z regionem, jego społeczeństwem i kulturą, z którą często wiąże się gotowość do altruistycznych działań na rzecz owego regionu czy społeczności,

- socjologicznej, w której zasadniczą rolę odgrywa - artykułowany lub nie - podział na my i oni, odczuwane poczucie odrębności, z którego bierze się odwoływanie się do małych ojczyzn, często skonfederowanych, które nawet mimo konfliktów dla zewnętrznego obserwatora ja-

20 Tamże.

21 A. Laszuk, dz. cyt., s. 176.

22 Podaję za: W. Stępniak, Nieporozumienie dotyczące pamięci świata, „Problemy Archiwistyki” 2009, nr 2 (4), s. 18.

23 J. Skowronek, dz. cyt., s. 13.

24 Por. A. Sosnowski, Tożsamość regionalna, narodowa, europejska-poziomy wspótczesnej identyfikacji spotecznej Polaków. Spojrzenie socjologa, Olsztyn 2008, s. 5.

25 Wedle koncepcji Marka S. Szczepańskiego. Podaję za: A. Sosnowski, dz. cyt., s. $6-7$. 
wią się jako spójne, a w wypadku zewnętrznego „zagrożenia” prezentują się jako zintegrowane,

- ekonomicznej, wynikającej zarówno z kooperacji, jak i konkurencji w skali lokalnej (i powyżej niej), będącej elementem trwania, lecz także rozkładu elementów tożsamości lokalnej,

- politologicznej, odnoszącej się do względnie trwałych preferencji politycznych mieszkańców regionu, wyrażającej się w wyborach wszystkich szczebli, jak i w instytucjonalnej oprawie działań politycznych, historycznych tradycjach ugrupowań politycznych i ruchów społecznych zaangażowanych w walkę o władzę,

- historycznej, powiązanej z indywidualnym (psychologicznym) i społecznym (oznaczającym zbiorowe przeżywanie) związkiem z dziejami regionu, jego bohaterami i historycznymi instytucjami,

- antropologicznej i etnograficznej, wiążących się z występowaniem specyficznych dla regionu elementów, tj. stroju, obyczajów, świadomości dziedzictwa kulturowego, rozumienia i odczytywania znaczeń, symboli kultury materialnej oraz jej korelatów, jak również języka, gwary i regionalnej literatury,

- geograficznej, równającej się przypisaniu do terytorium - miejsca i przestrzeni, a zwłaszcza rodzinnego domu (elementu prywatnej ojczyzny, czasem dla kilku pokoleń),

- urbanistyczno-architektonicznej, w której głównym czynnikiem są dominujące na danym obszarze tradycyjne, „ludowe” formy budowlane i rozwiązania architektoniczne, o zbliżonych lub identycznych cechach i parametrach technicznych oraz planistycznych.

Świadectwa określonej tożsamości lokalnej, tak jak w przypadku dziedzictwa narodowego są uchwytne zarówno w wymiarze niematerialnym, jak i materialnym. Zastrzegam, że koncentruję się na materialnych aspektach owej tożsamości, konkretnie na dokumentacji, z uwagi na swój substancjalny charakter stanowiącej domenę m.in. różnych archiwów.

Przejdę teraz do uwag poświęconych znaczeniu archiwów społecznych z punktu widzenia archiwalnego dziedzictwa narodowego. Gdy zacząłem się nad tym zastanawiać, pierwszą myślą było to, że ich rola może być dosyć skromna. Albowiem to, co ma mieć znaczenie dla (całego) narodu, chyba nie tylko mi kojarzy się zrazu z aktami instytucji i organizacji szczebla centralnego, czołowych polityków, działaczy i osobistości z natury rzeczy przyjmujących ogólnopaństwową perspektywę wraz z katalogiem spraw ważnych 
dla szerokich mas społeczeństwa. Takiej dokumentacji w zasobie archiwów społecznych raczej próżno szukać. Szybko jednak doszedłem do wniosku, że taki punkt widzenia nie byłby słuszny. Dzieje narodu uznaje się przecież za sumę wiedzy o dziejach lokalnych ${ }^{26}$. Dokumenty wprost odnoszące się do tych ostatnich pośrednio są substratem tych pierwszych. Aczkolwiek można rzec, że treść dokumentacji konstytuującej dziedzictwo narodowe par excellence, mówiąc nieco górnolotnie, porusza w sercach ludzi świadomych przynależności do danego narodu bardzo określone struny, różne od tych, które wybrzmiewają w kontakcie z dokumentami ściśle związanymi z lokalną tożsamością. Innego rodzaju przeżyciem jest przecież oglądanie fotografii ukazujących odpowiednio zabitych przez UB partyzantów podziemia niepodległościowego oraz strażaków-ochotników przejeżdżających przez miasto ${ }^{27}$. Uświadamianie sobie tych odmienności nie wyklucza wszakże sytuacji wywoływania u odbiorców informacji archiwalnej odczuć, w których zbliżają się do siebie lub wręcz przeplatają ze sobą te dwie sfery ${ }^{28}$. Dziedzictwo narodu to także jego zbiorowe doświadczenia. Nawet gdy w archiwaliach odzwierciedlane są przez pryzmat losów poszczególnych jednostek, rodzin lub małych społeczności, nieodmiennie wiążą się z tym, czym naród jako określona całość się interesuje, co sobie ceni albo co boleśnie przeżywa. Aby nie przesadzić z liczbą egzemplifikacji, nawiążę w tym kontekście tylko do dwóch materii: działań przedstawicieli narodu polskiego nieustannie dążących do osiągnięcia niepodległego/suwerennego bytu swego państwa oraz narodowej martyrologii związanej z masowym wywożeniem Polaków przez Sowietów

26 Por. A. Kociszewski, Książka historyczna w dziatalności stowarzyszeń regionalnych, [w:] Region i ludzie a historiografia i tożsamość. Materiaty z II Zjazdu Historyków w Gdańsku-Starbieninie, 22-24 XI 1996, oprac. J. Borzyszkowski, Gdańsk-Ciechanów 1999, s. 26.

27 By doświadczyć podobnych kontrastów w odbiorze archiwalnej ikonografii, można przejrzeć np. obfitujące w fotografie publikacje tj. Atlas Polskiego Podziemia Niepodlegtościowego, Warszawa-Lublin 2007 i Cyfrowe Archiwa Tradycji Lokalnej. Przewodnik, Warszawa 2014.

28 Jako przykład mogę wskazać wywołane podczas „spotkania z dokumentem” poczucie dumy u jednego z jego uczestników z powodu przynależności do lokalnej społeczności, która w przeszłości wykazała się bohaterskimi czynami, tj. udział w powstaniu narodowym. Zob. M. Bandurka, Archiwa wspótczesne w regionie (refleksje dtugoletniego archiwisty), [w:] Archiwa polskie wobec wyzwań XXI wieku. Pamiętnik III Powszechnego Zjazdu Archiwistów Polskich, Toruń 2-4 września 1997, red. D. Nałęcz, t. 2, Warszawa 1998, s. 24. 


\section{Tomasz Czarnota}

na Syberię i w inne rejony ZSRR. Bezcenne źródła obrazujące te zagadnienia można odnaleźć zwłaszcza w dwóch społecznych archiwach: krakowskim Centrum Dokumentacji Czynu Niepodległościowego i warszawskim Ośrodku Karta. Wiele innych zjawisk ważnych dla narodu również znajduje odbicie $\mathrm{w}$ dokumentach przechowywanych w archiwach społecznych. Ich zbieranie, udostępnianie i eksponowanie, szczególnie w przystępnych formach wydawnictw, wystaw i wirtualnych galerii ma wielkie znaczenie dla polskiego dziedzictwa narodowego.

Jeśli w przypadku znaczenia archiwów społecznych dla owego dziedzictwa ktoś mógłby mieć wątpliwości, to z pewnością nie miałby do nich prawa w odniesieniu do roli tych ośrodków w budowaniu i podtrzymywaniu tożsamości lokalnej. Zdecydowana większość z nich koncentruje się na lokalnej problematyce i historii ${ }^{29}$. Dotyczy to przeważającego odsetka spośród circa 430 podmiotów wpisanych do bazy danych prowadzonej przez Ośrodek Karta na stronie www.archiwa.org, a najpewniej są takie, których tam (jeszcze) nie uwzględniono. Ich znacząca rola nie sprowadza się tylko do tego, że aktywnie zajmują się zbieraniem dokumentacji bezpośrednio nawiązującej do lokalnej tożsamości. Poza tym czynnie włączają się w jej kształtowanie za pomocą różnych metod (np. sesji popularnonaukowych, wydarzeń rekonstrukcyjnych). Można im też przypisać zachęcanie różnych grup społecznych do prowadzenia działalności dokumentacyjnej i budowania swej pamięci oraz podnoszenie ich świadomości dokumentacyjnej ${ }^{30}$. Ponadto, co jest charakterystyczne dla tych ośrodków, liczą one na partycypowanie w ich działalności zainteresowanej nią części społeczeństwa i - jak pokazują dotychczasowe doświadczenia - rachuby te nie zawodzą ${ }^{31}$. Stwarzanie przedstawicielom lokalnych społeczności możliwości bezpośredniego udziału np. w opisywaniu zamieszczanych w internecie fotografii to znakomity mechanizm rozwijania ich zainteresowań i zarazem pobudzania troski o ich „małe ojczyzny”. Sprzyja to też rozwojowi lokalnej historiografii. Przyjmowanie lokalnego horyzontu wpływa nie tylko na budzenie uczuć patriotycznych, ale i na propagowanie nowoczesnych trendów w humanistyce, jak mikrohistoria, historia codzien-

29 K. Ziętal, Ustanowienie AS-ów, s. 140.

$30 \mathrm{O}$ tych zagadnieniach zob. A. Rosa, Funkcja edukacyjna archiwów, Warszawa 2012, s. 44, 137-138.

31 M. Wilkowski, Wprowadzenie do historii cyfrowej, Gdańsk 2013, s. 41. 
ności i historia mentalności ${ }^{32}$. Dziś generalnie oczekuje się, że archiwa i im podobne placówki zamiast pasywnie czekać na zjawienie się użytkowników, wyjdą do ludzi, pokazując im w toku realizacji swych funkcji edukacyjnej i promocyjnej, jakie pożytki z ich istnienia mogą oni odnosić3 ${ }^{33}$ W ich ramach odbywać się będą działania sprzyjające współtworzeniu, odkrywaniu i rozwijaniu, a także umacnianiu w ludziach tej tożsamości. W tym celu archiwa powinny sięgać do możliwie szerokiego instrumentarium metod i technik. Lecz nie można oczekiwać, by czyniły to inaczej niż na miarę swych możliwości i środków (finansowych, technicznych) i w oderwaniu od różnorakich ograniczeń. Skupię się teraz na tym ostatnim wątku w odniesieniu do archiwów państwowych i społecznych.

Jakie trudności pętają działania państwowych archiwów? Chociaż są one częścią omnipotentnej zdawałoby się machiny państwowej, w obecnych realiach nie mają możliwości całkowitego wywiązania się z naczelnego zadania, jakim jest opieka nad całym narodowym zasobem archiwalnym. Prawne, ale też i inne przyczyny (np. organizacyjne) sprawiają, że nie gromadzą one - nie realizują więc i innych zadań - w sposób systematyczny materiałów archiwalnych powstających poza instytucjami sektora publicznego. $\mathrm{Z}$ ich strony obecnie padają wyraźne deklaracje o niepretendowaniu do zajmowania się dokumentacją każdego podmiotu ${ }^{34}$. Postulatom szeregu autorów upominających się w ostatnich kilku dekadach o zmiany w systemie selekcji archiwalnej i gromadzenie przez państwowe archiwa także innych źródeł niż registratury urzędów i instytucji, z tych powodów mogą one jedynie częściowo zadośćuczynic $^{35}$. Tego typu ograniczenia w mniejszym natomiast stopniu dotyczą

32 W. Chorążyczewski, Archiwista przysztości - edukator i autopromotor $w$ spoteczeństwie informacyjnym, [w:] Archiwa w nowoczesnym spoteczeństwie. Pamiętnik V Powszechnego Zjazdu Archiwistów Polskich, Olsztyn 6-8 września 2007 r., red. J. Porazinski i K. Stryjkowski, Warszawa 2008, s. 51.

33 Zob. tamże, s. 49.

34 Wypowiedź ta znalazła się w referacie Naczelnego Dyrektora Archiwów Państwowych prof. Władysława Stępniaka pt. Archiwa państwowe wobec wytwórców niepaństwowego zasobu archiwalnego wygłoszonym podczas Międzynarodowej Konferencji Archiwa Społeczne. Modele Współpracy z Państwem (Warszawa, 6 X 2014 r.).

35 Zob. m.in.: T. Grygier, Wspótczesne zadania dokumentacyjne archiwów, „Archiwa, Biblioteki i Muzea Kościelne” 1981, t. 42, s. 14; M. Bandurka, dz. cyt., s. 25; A. Rosa, Egodokumenty a dziatalnossć archiwów, [w:] Zatrzymać przesztość, dogonić przysztość, s. 272, 275. 
archiwów społecznych ${ }^{36}$. Ich działalność jest w dużej mierze komplementarna względem prowadzonej przez ich państwowe odpowiedniki. Dysponują one możliwościami zebrania, zabezpieczenia, a nawet wywołania ${ }^{37}$ takich dokumentów, które tylko przypadkiem, np. jako dary, trafiają do ich archiwów państwowych i są dla nich praktycznie nieosiągalne. Nieco podobnie przedstawia się kwestia tempa opracowywania dokumentów. Zasób większości lub nawet wszystkich archiwów państwowych jest pełni zewidencjonowany, ale do wielu zespołów lub ich fragmentów wykonano jedynie podstawowe pomoce ewidencyjne (spisy robocze), inne z kolei posiadają wyłącznie dostarczone razem z aktami spisy zdawczo-odbiorcze. Stan ten wynika z dużych rozmiarów cyklicznie archiwizowanego państwowego zasobu archiwalnego. Tego, za który bezpośrednio odpowiadają. Mogę się mylić, lecz przypuszczam, że gdyby nagle zaczęły do archiwów państwowych szerokim strumieniem napływać te wszystkie materiały, którymi obecnie zajmują się archiwa społeczne, mogłyby one mieć problem nie tylko z ich odpowiednim rozlokowaniem, lecz także z szybkim opracowaniem i udostępnieniem. W przypadku materiałów, tj. fotografii lub pamiętników, upływający czas nie sprzyja wysokiej jakości opracowania. Zatarciu ulega istotny dla tej czynności kontekst ich powstania i funkcjonowania, a ewentualne źródła dodatkowych informacji wysychają ${ }^{38}$.

Lecz archiwa społeczne także borykają się z wieloma problemami. Jednym z ważniejszych i zarazem trudnym do wyeliminowania jest ich względna efemeryczność. Z reguły działają one dopóty, dopóki starcza energii i środków osobom stojącym za ich powstaniem. Ich brak oznacza narażenie zasobu na rozproszenie lub fizyczne unicestwienie. W nie mniejszym stopniu, choć z nieco innych powodów dotyczy to wirtualnych archiwów - witryn internetowych, których byt w dłuższej perspektywie czasowej też jawi się jako bardzo niepewny ${ }^{39}$. Im też zdarzają się opóźnienia z opracowaniem innych

36 Nie są one całkiem od niej wolne, gdyż formalnie nie wolno im gromadzić akt współczesnych organizacji społecznych i politycznych.

37 Czyli wykreowania ich dzięki nagrywaniu relacji i wspomnień oraz innym działaniom, np. konkursom na prace o określonej tematyce historycznej. Trzeba przyznać, że podobne konkursy, np. „Zostań rodzinnym archiwistą” (w 2013 r. zaowocował on publikacją pt. Archiwa rodzinne) organizują też archiwa państwowe.

38 Chociażby w związku z wymieraniem tych, którzy mogliby rzucić na to światło, np. pomagając opisać fotografie bądź weryfikując niektóre dane zawarte w różnych „egodokumentach”. W przypadku akt przesyconych formalizacją instytucji publicznych, sprawa ich opracowania przestawia się zgoła inaczej.

39 D. Magier, dz. cyt., s. 26. 
narzędzi informacji niż podstawowe pomoce ewidencyjne ${ }^{40}$. Kolejnym problemem wielu archiwów społecznych jest niedostatek środków finansowych potrzebnych do realizacji podstawowych zadań, tj. gromadzenia, należytego przechowywania i udostępniania ${ }^{41}$. Bywają one zmuszone do ich realizacji w ograniczonym zakresie właśnie z tych powodów, nie zaś z braku chęci czy nawet umiejętności. Inne z kolei nieustannie przeznaczają mnóstwo czasu i energii na poszukiwanie tych środków, zapewne nie bez szkody dla innych działań. „Społeczni archiwiści”, choć pełni zapału i inicjatywy, nierzadko nie mają dostatecznie rozległej wiedzy i umiejętności, by profesjonalnie prowadzić działalność archiwalno-dokumentacyjną. Nie trzeba nikomu specjalnie tłumaczyć, że w każdym rodzaju działalności, zawodowej bądź hobbystycznej, prowadzącym ją pomaga korzystanie z wiedzy tych, którzy na tym lub pokrewnym polu zdobyli doświadczenie. Nawet wśród uczestników i orędowników tego ruchu wyrażane są opinie, z którymi się zgadzam, że archiwa społeczne mimo swego oddolnego i pozornie amatorskiego charakteru powinny spełniać podstawowe zasady pracy archiwistycznej, by różnić się tym od zupełnie efemerycznych inicjatyw o podobnych celach ${ }^{42}$. A po co mozolnie poszukiwać, testować i poprawiać własne pomysły, skoro archiwalnego know how można nauczyć się od innych, ewentualnie dostosowując go do swych potrzeb?

Jak widać, po obu stronach występują pewne, lecz nie identyczne niedostatki i trudności. Z częścią z nich każdy z tych typów archiwów musi mierzyć się samodzielnie. Ale poza tym jest też niewąska przestrzeń, w której mogą one działać razem. Czy bezwzględnie muszą? Nie wydaje mi się, by był do obronienia pogląd, że archiwa społeczne i państwowe nawzajem są na siebie skazane. Mogą funkcjonować obok siebie, nie pozostając w żadnej formie zależności, gdyż pomijając inne okoliczności, właściwy im przedmiot działania, czyli odpowiednio materiały publicznej lub niepublicznej proweniencji, mają odmienny. Ale niewątpliwie takie współdziałanie jest możliwe. Zaistniałe dotychczas fakty wspólnych przedsięwzięć ${ }^{43}$ przekonują, że jest i bę-

40 Zob. H. Chudzio, A. Hejczyk, Zbiory Centrum Dokumentacji Zsytek, Wypędzeń i Przesiedleń, „Archeion” 2013, t. 104, s. 92.

41 Zob. G. Sołtysiak, $Z$ doświadczeń pracy w Archiwum Dokumentacji Historycznej PRL, „Archeion” 2013, t. 104, s. 79.

42 Zob. M. Wilkowski, Archiwa w bibliotekach, „Karta” 2012, nr 71, s. 145.

$43 \mathrm{Z}$ najnowszych można wymienić chociażby wspólny udział szeregu archiwów państwowych i Ośrodka Karta w V Warszawskim Pikniku Archiwalnym (7 VI 2014 r.). 
dzie ono potrzebne obywatelom, na rzecz których one działają - żyjącym współcześnie oraz następnym pokoleniom. Ponadto może ono być obopólnie korzystne. Wspólne spotkania (sesje, konferencje itd.) są istotną z punktu widzenia PR okazją do promowania siebie w lokalnej społeczności ${ }^{44}$. Tą przestrzeń, o której wspomniałem, wytyczają: zbieżność celów cząstkowych, tj. gromadzenia, przechowywania, opracowywania i udostępniania dokumentacji o nieprzemijającej wartości, oraz wspólnota celów zasadniczych, których z kolei upatruję w dbałości o polskie dziedzictwo narodowe i tożsamość lokalną. Ekonomia uczy, że współpraca generuje synergię - zwielokrotniony efekt nieosiągalny w warunkach izolowanych działań. Zatem zwykła kalkulacja i zdrowy rozsądek, do pary ze świadomością pokrewieństwa celów skłaniają ku jej podjęciu. I nie tylko one. Niepodejmowanie jej stałoby nawet w sprzeczności z kodeksem etycznym obowiązującym wszystkich archiwistów. Kilka jego punktów nawołuje do niej bezpośrednio ${ }^{45}$. Czy uwzględniając ze wszech miar korzystne i społecznie oczekiwane rezultaty współpracy archiwom państwowym i społecznym wolno się od niej uchylać?

Można więc przyjąć, że istnieje konsensus co do tego, by dyskutować nie tyle o zasadności współpracy tych archiwów, bo ten zdaje się oczywisty, ile o jej przedmiocie i zakresie. Czas więc, by zasygnalizować to, co konkretnie obie wymienione instytucje pamięci mają sobie wzajemnie do zaoferowania. Jaki wkład dla realizacji wspólnej misji, jaką jest odzwierciedlenie w archiwalnej dokumentacji całego procesu rozwoju społecznego ${ }^{46}$, każda z nich może wnieść? Zasygnalizuję lub raczej zreasumuję (kwestie te bowiem są poruszane w literaturze) kilka podstawowych płaszczyzn współpracy, bez rozwijania w szczegółach tej obszernej i złożonej problematyki. Przedmiot tej współpracy określiłbym jako wzajemną pomoc na rzecz bardziej efektywnego prowadzenia działalności archiwalnej w formach i zakresie właściwych obu typom archiwów. Do tego dodałbym realizację wspólnych inicjatyw (np. wy-

44 Por. M. Jabłońska, Komunikacja spoteczna i public relations $w$ archiwach. Zarys problematyki badawczej, [w:] Archiwa-Kancelarie - Zbiory, t. 2, red. W. Chorążyczewski, R. Degen, K. Syta, t. 2, Toruń 2008, s. 75.

45 Chociażby pkt 10 dotyczący powinności podejmowania przez archiwistów współpracy z ludźmi tej samej lub pokrewnych profesji na rzecz zabezpieczania i wykorzystywania najszerzej rozumianej spuścizny archiwalnej czy pkt 9 wzywający ich do stałego doskonalenia posiadanych umiejętności i dzielenia się z innymi swym doświadczeniem i wynikami badań. Kodeks etyczny archiwisty, http://www.sap.waw.pl/node/27 [dostęp: 8 VI 2014 r.].

46 Por. C. Biernat, Problemy archiwistyki wspótczesnej, Warszawa 1977, s. 26. 
staw, edycji źródłowych, wymiany informacji o swych zasobach, warsztatów), w których chodziłoby o to, by odpowiednio do możliwości oraz specyfiki łącznie wnosiły one wkład w propagowanie i ochronę dziedzictwa narodowego i tożsamości lokalnej. Z kolei zakres tej współpracy wytyczałyby w sposób stały ich określone potrzeby, związane zwłaszcza z utrzymującymi się niedogodnościami w ich działalności, rzutującymi negatywnie na jej rezultaty. Przy realizacji konkretnych wspólnych przedsięwzięć zakres podjętej współpracy każdorazowo wynikałby z ich charakteru i związanych z nim wymagań.

Ustalmy teraz, co faktycznie mają one sobie do zaoferowania. Chodzi w głównej mierze o transfer będących u jednej ze stron „w deficycie” umiejętności niezbędnych w działalności archiwalnej. W pierwszej kolejności wskazałbym na niektóre kompetencje potrzebne do wykonywania podstawowych zadań archiwów, tj. przechowywania, opracowania ${ }^{47}$ i udostępniania dokumentacji, z uwzględnieniem dziś szczególnie majoryzowanych funkcji edukacyjnej i popularyzacyjnej. W tej ostatniej dziedzinie większą aktywność wykazują archiwa społeczne ${ }^{48}$. Natomiast wyłączyłbym z tego raczej doświadczenia związane z gromadzeniem materiałów specyficznych dla nich i dla archiwów państwowych. Ich różny status prawny, proweniencja i szereg innych cech szczególnych według mnie sprawia, że każdy z tych typów archiwów będzie na tym polu działać według dotychczas wypracowanych metod $^{49}$. Inne zadania dzięki nawzajem podsuwanym pomysłom, udzielanym poradom i przeprowadzanym dyskusjom i warsztatom na pewno często da się wykonywać lepiej aniżeli przed nawiązaniem współdziałania. We wzajemnej ofercie znajduje się także szereg praktycznych umiejętności, klasyczny know how opracowywania ${ }^{50}$, konserwacji i digitalizacji archiwaliów. Realizacja każdego z tych zadań także dzięki obserwowaniu i choćby częściowemu zapożyczeniu sprawdzonych u partnera metod, standardów i technik bez wątpienia okazała by się sprawniejsza. Poza przepływem szeroko rozumia-

47 W literaturze są uchwytne postulaty opracowania wspólnych zasad opracowania dla zbiorów archiwów społecznych. Zob. G. Sołtysiak, dz. cyt., s. 81.

48 A. Rosa, Funkcja edukacyjna, s. 104.

49 Wyjątkiem mogłoby tutaj być dzielenie się pozyskanymi informacjami o istnieniu dokumentów znajdujących się wybitnie w centrum zainteresowania jednego z tych archiwów, takich, które chciałoby ono dla siebie pozyskać.

50 Do przekazania przez archiwa ich doświadczeń m.in. w zakresie archiwalnej informatyki (technicznych czynności dokumentacji) innym instytutom dokumentacyjnym wzywał już kilka dekad temu T. Grygier, Wspótczesne zadania dokumentacyjne, s. 44. 
nych idei można też sobie wyobrazić dzielenie się posiadanymi technologiami informacyjnymi i użyczanie sobie narzędzi np. informatycznych (choć nie tylko $^{51}$, służących optymalizacji opracowania i udostępniania. W pewnym zakresie w grę może też wchodzić bezpośrednie wykonywanie na rzecz partnera niektórych usług, np. związanych z zabiegami konserwatorskimi oraz digitalizacją. Last but not least: w sytuacji, gdy w poszczególnych archiwach społecznych zanikną możliwości lub wola kontynuowania dotychczasowej działalności, archiwa państwowe będą też mogły występować w roli naturalnych sukcesorów ich zbiorów, które za ich zgodą (wyrażoną np. w formie umów darowizny) przejmowałyby pod swoją opiekę ${ }^{52}$. Udzielanie sobie przez archiwa bezpośredniej pomocy finansowej nie jest możliwe ze względów formalnych. Lecz nie oznacza to, że zainteresowanym nią społecznym ośrodkom dokumentacji, skądinąd mającym doświadczenia w jej pozyskiwaniu, partnerzy z państwowej służby archiwalnej nie mogą udzielać wskazówek, do kogo i w jakiej formie się o nią zwracać.

Zaprezentowane uwagi poświęcone archiwom społecznym i ich znaczeniu dla polskiego dziedzictwa narodowego i tożsamości lokalnej nie wyczerpują tej problematyki. Wynika to przede wszystkim z aktualnego stanu wiedzy w tej materii. Jestem wszakże przekonany, że będzie się ona sukcesywnie zwiększać. Zwłaszcza że zainteresowanie tymi zagadnieniami generalnie zdaje się rosnąć. Obecnie w Polsce - kraju członkowskim Unii Europejskiej uwidacznia się coraz silniejsze oddziaływanie ze strony tej ostatniej. Jej uwaga skupia się również na zagadnieniach, których dotyczył ten artykuł. Zachowanie narodowych oraz regionalnych różnorodności w sferze kulturalnej, przy jednoczesnym zaznaczaniu wspólnego dziedzictwa kulturowego państw - członków Unii jest ideą jednoznacznie wyrażoną w założycielskim traktacie z Maastricht z 1992 r. ${ }^{53}$ Obywatele Polski i zarazem Unii mogą czuć się zachę-

51 Jeżeli jedno z archiwów dysponuje np. rzadziej spotykanym sprzętem do odtwarzania analogowych nośników informacji (np. taśm z nagraniami), którego nie posiada drugie, to użyczenie go chociażby w celu przekopiowania go na inny nośnik też jest nie bez znaczenia.

52 Mogłoby to też dotyczyć archiwizacji prowadzonych przez te archiwa witryn internetowych będących repozytoriami dokumentów w formie elektronicznej.

53 Por. W. Stępniak, Archiwa w polityce europejskiej. Uwagi wstępne, [w:] Archiwa $w$ nowoczesnym spoteczeństwie, s. 23. 
cani do jej realizacji. Zwłaszcza że oficjalne dokumenty unijne potwierdzają to, że „zwykli” ludzie też uczestniczą w procesie gromadzenia, chronienia, opisywania i wzbogacania dziedzictwa kulturowego oraz że pamięć społeczna ulokowana jest nie tylko w archiwach publicznych, lecz także u właścicieli źródeł, tworząc strukturę lokalnej, regionalnej i narodowej pamięci oraz historii, jak też historii i tożsamości politycznych, religijnych i innych grup społecznych $^{54}$. Jest więc chyba konsensus co do tego, że istotną rolę w tych procesach mogą odegrać zarówno osoby fizyczne, jak i prawne. Niewątpliwie w pewnym zakresie robią to zarówno archiwa państwowe i społeczne. Należy postulować, aby - w dalszym ciągu i jeszcze intensywniej - działały wspólnie. Od rezultatów ich poczynań w wielkiej mierze zależeć będzie to, jaką schedę pozostawimy tym, którzy przyjdą po nas.

Bibliografia:

Atlas Polskiego Podziemia Niepodlegtościowego, Warszawa-Lublin 2007.

Bandurka Mieczysław, Archiwa wspótczesne w regionie (refleksje dtugoletniego archiwisty), [w:] Archiwa polskie wobec wyzwań XXI wieku. Pamiętnik III Powszechnego Zjazdu Archiwistów Polskich, Toruń 2-4 września 1997, red. D. Nałęcz, t. 2, Warszawa 1998.

Biernat Czesław, Problemy archiwistyki wspótczesnej, Warszawa 1977.

Borychowski Rafał, Archiwalne dziedzictwo narodowe a narodowy zasób archiwalny, [w:] Zatrzymać przesztość, dogonić przysztość. Pamiętnik VI Powszechnego Zjazdu Archiwistów Polskich, Wroctaw 5-7 września 2012 r., red. W. Chorążyczewski i K. Stryjkowski, Warszawa 2013.

Chorążyczewski Waldemar, Archiwista przysztości - edukator i autopromotor w spoteczeństwie informacyjnym, [w:] Archiwa w nowoczesnym spoteczeństwie. Pamiętnik V Powszechnego Zjazdu Archiwistów Polskich, Olsztyn 6-8 września 2007 r., red. J. Porazinski i K. Stryjkowski, Warszawa 2008.

Chudzio Hubert, Hejczyk Anna, Zbiory Centrum Dokumentacji Zsytek, Wypędzeń i Przesiedleń, „Archeion” 2013, t. 114, 2013.

Cyfrowe Archiwa Tradycji Lokalnej. Przewodnik, Warszawa 2014.

Grygier Tadeusz, Wspótczesne zadania dokumentacyjne archiwów, „Archiwa, Biblioteki i Muzea Kościelne" 1981, t. 42.

Grygier Tadeusz, Zagadnienia podziatu wewnętrznego archiwistyki, „Archeion” 1979, t. 68.

54 Raport o archiwach w Unii Europejskiej, s. 171. 


\section{Tomasz Czarnota}

Jabłońska Marlena, Komunikacja spoteczna i public relations $w$ archiwach. Zarys problematyki badawczej, [w:] Archiwa - Kancelarie - Zbiory, red. W. Chorążyczewski, R. Degen, K. Syta, t. 2, Toruń 2008.

Kociszewski Aleksander, Ksiązka historyczna $w$ dziatalności stowarzyszeń regionalnych, [w:] Region i ludzie a historiografia i tożsamość. Materiaty z II Zjazdu Historyków w Gdańsku - Starbieninie, 22- 24 XI 1996, oprac. J. Borzyszkowski, Gdańsk-Ciechanów 1999.

Kodeks etyczny archiwisty [on line], http://www.sap.waw.pl/node/27 [dostęp: 8 VI 2014 r.].

Laszuk Anna, Archiwa częścia dziedzictwa narodowego - standardy podstawa wspótpracy, [w:] Toruńskie konfrontacje archiwalne, red. W. Chorążyczewski i A. Rosa, t. 3: Archiwistyka między różnorodnościa a standaryzacją, Toruń 2013.

Magier Dariusz, Archiwistyka wobec wyzwań świata cyfrowego, „Archiwista Polski” 2010, nr 4.

Ochrona dziedzictwa cyfrowego. Zalecenia, Warszawa 2003.

Polski stownik archiwalny, red. W. Maciejewska. Warszawa 1974.

Raport o archiwach $w$ Unii Europejskiej po rozszerzeniu. Pogtębiona wspótpraca archiwalna w Europie. Plan dziatania, Warszawa 2012.

Rosa Agnieszka, Egodokumenty a dziatalność archiwów, [w:] Zatrzymać przesztość, dogonić przysztość. Pamiętnik VI Powszechnego Zjazdu Archiwistów Polskich, Wroctaw 5-7 września 2012 r., red. W. Chorążyczewski i K. Stryjkowski, Warszawa 2013.

Rosa Agnieszka, Funkcja edukacyjna archiwów, Warszawa 2012.

Skowronek Jerzy, Misja archiwisty i problemy rewindykacji archiwów - specyfika Europy Środkowo-Wschodniej XIX i XX w., „Archeion” 1995, t. 94.

Stownik języka polskiego, hasta: znaczenie, znaczyć, http://sjp.pl/znaczenie [dostęp: $26 \mathrm{~V}$ 2014 r.]

Sołtysiak Grzegorz, $Z$ doświadczeń pracy w Archiwum Dokumentacji Historycznej PRL, „Archeion” 2013, t. 114.

Sosnowski Adam, Tożsamość regionalna, narodowa, europejska - poziomy wspótczesnej identyfikacji spotecznej Polaków. Spojrzenie socjologa, Olsztyn 2008.

Stępniak Władysław, Archiwa w polityce europejskiej. Uwagi wstępne, [w:] Archiwa w nowoczesnym spoteczeństwie. Pamiętnik V Powszechnego Zjazdu Archiwistów Polskich, Olsztyn 6-8 września 2007 r., red. J. Porazinski i K. Stryjkowski, Warszawa 2008.

Stępniak Władysław, Nieporozumienie dotyczące pamięci świata, „Problemy Archiwistyki” 2009, nr 2 (4).

Stępniak Władysław, Program UNESCO Memory of the World, „Archeion” 1994, t. 93.

Wilkowski Marcin, Archiwa w bibliotekach, „Karta” 2012, nr 71.

Wilkowski Marcin, Wprowadzenie do historii cyfrowej, Gdańsk 2013.

Ziętal Katarzyna, Wstęp, [w:] Archiwistyka spoteczna, Warszawa 2012.

Ziętal Katarzyna, Ustanowienie AS-ów, „Karta” 2013, nr 75. 


\section{Summary}

About community archives and its meaning for Polish national heritage and local identity

Community archives display notable activity, especially during last years. Due to that they have become a significant element of the system of archives in Poland. But there are still a number of basic problems, not only theoretical, concerning their activity, that must be set down: their formal status (also: their holdings status), their place in system of Polish archives (in the broad sense), and shape of their relations to other archives (especially state ones). Moreover, corresponding to problems mentioned above, their fundamental meaning to national heritage and local identity must be looked into. Taking a thesis of Jerzy Skowronek, that the archival national heritage are all archival materials produced by a particular nation and state, regardless of place of keeping, the holdings of community archives must be seen as that. But not always they are simply associated with phenomena, processes or events that are crucial from the point of view of a nation as a whole. Whereas these holdings, according to a scope of their collection, are direct and very accurate reflection of local history. This makes community archives main creators and protectors of local identity, especially with common practice among community archives, that consists in dragging local communities into cooperation in making the history and, in general, into cooperating with them. Their mission, in both of these spheres, is carried out in a condition of a dichotomy. On the one hand there is intentional using of assets: creativity, enthusiasm and a special ability to reach to sources that are unavailable to other potential rivals. On the other hand, a full success is impediment due to various limitations, especially often observed financial fragility and lack of certainty of existence in a longer time perspective. Whereas state archives, having no problems in that area, due to some formal and organizational reasons cannot impact the non-state branch of the national archival holdings effectively. That, and a number of other reasons should induce both types of archives to strengthen contacts between them and to take up or intensify collaboration in various fields. It will result in increasing efficiency of archival activity performed by them separately. 
